\title{
An Entrepreneurial Self-Efficacy Scale with a Neutral Wording
}

\author{
Moberg, Kåre
}

Document Version

Final published version

Publication date:

2012

\section{License \\ CC BY-NC-ND}

Citation for published version (APA):

Moberg, K. (2012). An Entrepreneurial Self-Efficacy Scale with a Neutral Wording. Institut for Strategic Management and Globalization. SMG Working Paper No. 6/2012

Link to publication in CBS Research Portal

\section{General rights}

Copyright and moral rights for the publications made accessible in the public portal are retained by the authors and/or other copyright owners and it is a condition of accessing publications that users recognise and abide by the legal requirements associated with these rights.

\section{Take down policy}

If you believe that this document breaches copyright please contact us (research.lib@cbs.dk) providing details, and we will remove access to the work immediately and investigate your claim. 
An Entrepreneurial Self-Efficacy Scale with a Neutral Wording

Kåre Moberg

SMG WP 6/2012

October, 2012 
SMG Working Paper No. 6/2012

October, 2012

ISBN: 978-87-91815-82-9

Department of Strategic Management and Globalization Copenhagen Business School

Kilen, Kilevej 14A

2000 Frederiksberg

Denmark

www.cbs.dk/smg 


\title{
An Entrepreneurial Self-Efficacy Scale with a Neutral Wording
}

\author{
Kåre Moberg, \\ Dept. of Strategic Management and Globalization \\ Copenhagen Business School \\ and \\ The Danish Foundation for Entrepreneurship - Young Enterprise \\ Email: kaare@ffe-ye.dk \\ Prepared for:

\begin{abstract}
CONCEPTUAL RICHNESS AND METHODOLOGICAL DIVERSITY IN ENTREPRENEURSHIP REASEARCH: ENTREPRENEURSHIP RESEARCH IN EUROPE, Alain Fayolle, Paula Kyrö,
\end{abstract} \\ Tonis Mets and Urve Venesaar (eds)., Edward Elgar, 2013.
}

October $25^{\text {th }}, 2012$

SMG WP 6/2012

Key words: entrepreneurial self-efficacy, entrepreneurship education, confirmatory factor analysis, opportunity

JEL codes: A23, C83, I21, J24, L26,

\begin{abstract}
In this book chapter I present a multidimensional entrepreneurial self-efficacy (ESE) scale. The scale builds on three established ESE-scales, but the reliability of it is improved compared to the original three scales as the highly discipline-specific jargon is transformed to a more neutral wording of the items. The scale has been tested in a large scale survey including 445 students from twelve different programmes at three universities in Denmark and one university in Sweden. Exploratory factor analysis (EFA) has been applied in order to investigate the multidimensionality of the items in the scale, and confirmatory factor analysis (CFA) has been applied to investigate its convergent, discriminatory and nomological validity. The results demonstrate support for a multidimensional ESE-scale with high predictive validity regarding entrepreneurial behaviours and with high reliability as the items are comprehensible to respondents, regardless if they have entrepreneurial experience or not. The scale can thus be used in programme evaluations that include control groups or other type of individuals that lack entrepreneurial experience.
\end{abstract}




\section{Introduction}

Interest in entrepreneurship education has been growing immensely over the last decade (Kuratko, 2005). The changes in society and in the economy make the capacity to act entrepreneurially a necessary ability for all individuals, regardless if they work in established organizations or in newly created ventures (Gibb, 2002; Sarasvathy \& Venkataraman, 2011). Policy makers all around the world have begun to demand that universities incorporate entrepreneurship in their curricula (Honig, 2004). Today entrepreneurship should be offered to students of every discipline, not just at the business schools (Katz, 2003; 2008). This expansion outside of the business schools does, however, raise major challenges to programme evaluators who want to evaluate the impact of entrepreneurship courses and programmes. The measurement scales we use today are developed with active and practicing entrepreneurs in mind, and the language used is often heavily jargon-biased and hard for nonentrepreneurs to understand. This is critical when it comes to students outside of the business schools, as it cannot be expected that they understand the business-oriented questions in the measurement scales before they are actually taking an entrepreneurship course. As programme evaluations typically are structured as pre-test/post-test surveys, this raises the questions of reliability of these assessment-surveys.

The field of cognitive psychology has proven to be very helpful to evaluators who seek to measure the impact of entrepreneurship education (Krueger, 2009). In particular selfefficacy - i.e. the individual's perception that he/she can perform a specific task (Bandura, 1997) - has proven to be a very suitable theoretical basis for measurement of educational

programmes (Mauer, Neergaard and Kirketerp, 2009). The reason why self-efficacy has become so popular when it comes to educational programmes is that it is in line with 
education's raison d'être (Karlsson \& Moberg, forthcoming), which is to provide individuals with knowledge and skills within a specific area (Biggs and Tang, 2007). Task specific selfefficacy, in our case entrepreneurial self-efficacy (henceforth, ESE), provides us with the link between the effect of education on students' knowledge and the skill-sets, and how these knowledge and skill-sets influence entrepreneurial behaviour (Mauer et al., 2009). Numerous surveys have showed that ESE has a positive effect on entrepreneurial intentions and behaviours (Barbosa, Gerhardt and Kickul, 2007; McGee, Peterson, Mueller and Sequeira, 2009; Zhao, Seibert, and Hills, 2005). It can, however, be questioned how reliable these are, as the scales used in the surveys have a heavily jargon-biased wording.

In this book chapter I present an ESE-scale that uses a more neutral wording. The scale is based on contemporary entrepreneurship theory and three validated ESE-scales. The results are based on a larger scale survey including 445 students from twelve master programmes at three universities in Denmark and one university in Sweden. The text is divided into four sections. In the first section an overview of the theoretical background of entrepreneurship education is briefly described. This is followed by a description of different types of measurement tools that have been used in order to assess the impact of entrepreneurship education. In the second section the need for an ESE-scale with a more discipline-neutral wording is discussed and the development of a new ESE-scale is presented. In the third section the results of two tests of the scale is presented and discussed. The chapter ends with a discussion of the results and the limitations of the survey as well as suggestions for future research.

\section{Theoretical Background}


Entrepreneurship education is often mistakenly viewed as a homogeneous topic that can be taught to all types of students in the same way, regardless of their disciplinary background (Honig, 2004). The field has its roots in strategic management at American business schools and, thus, the focus is often on typical business management skills (ibid). In a very influential article, Shane and Venkataraman (2000) state that the focus of entrepreneurship research should be on opportunity-individual nexus, or more specifically when/why/how some individuals identify, evaluate and exploit opportunities when others do not. Especially the notion of opportunity identification and evaluation has had a major impact on entrepreneurship education, while the exploitation phase often is omitted (Foss \& Klein, 2012). This focus on the two first phases of an entrepreneurial venture process in educational settings can be explained with the fact that the skill-sets required in these phases are more in line with typical strategic management skills, i.e. analyzing, planning and evaluating (Honig, 2004). Given the explosive growth of the field during the last decades in which the number of students outside of the business schools has grown tremendously (Katz, 2003; 2008), this classical view of entrepreneurship has become problematic.

The extended educational scope of entrepreneurship education combined with the fact that the educational field still lags behind advances made within entrepreneurship research (Honig, 2004), raises the need for a rigorous understanding on what types of effects different educational designs have on different types of students (Rasmusen \& Sørheim, 2006). The field's focus on business management skills is primary challenged by British researchers who argue that it would be more viable to focus on the broader concept of enterprising behaviour rather than on more specific start-up skills (e.g. Gibb, 2002; Gibb \& Hannon, 2006; Rae, 2007). This change of focus would also make a break with disciplinary boundaries that hinder numerous students from getting skills that are needed in today's society (Gibb, 2002). 
Recently, it has actually been proposed that entrepreneurship should be viewed as a method rather than a discipline (cf. Sarasvathy \& Venkataraman, 2011; Neck \& Greene, 2011).

Another type of critique of the classical view of entrepreneurship, which has developed during the last decade, criticizes the field's focus on opportunity identification and argues instead that we should emphasize the creation of opportunity (cf. Alvarez \& Barney, 2007, 2010, 2012; Korsgaard, 2009). According to researchers that subscribe to the "creation view" of entrepreneurship, the uncertain and ambiguous context of entrepreneurial activities forces entrepreneurs to often ignore predictive methods such as market research and competitive analysis, which are typical for established organizations, and instead focus on control methods such as partnerships and iterations (cf. Sarasvathy, 2001).

A more synthetic view has recently been proposed by the neo-Austrian researchers Foss and Klein (2012), who propose that entrepreneurship should be viewed as the exercise of judgment under true uncertainty in order to decide on how to allocate resources. In their view, entrepreneurship is, however, not limited to the creation of new companies. Also within established organizations, entrepreneurial activities can take place in the form of corporate entrepreneurship (cf. Burgleman, 1984; Stevenson \& Jarillo, 1990; Zahra, 1991), or as strategic entrepreneurship (cf. Foss \& Lyngsie, 2011; Hitt, Ireland, Camp \& Sexton, 2001).

It is clear from this short review that entrepreneurship education is a heterogeneous field with many different perspectives. There is no real consensus regarding which type of skills are more important than others when it comes to new venture creation, and it is even contested what "real" entrepreneurial activity is actually about. In order to capture these different views, an ESE-scale needs to incorporate a large range of different skill-sets.

\section{Different measurements}


During the last decade, cognitive psychology has had a major impact on how outcomes of entrepreneurship programmes have been evaluated (Krueger, 2009). The topic of interest has mainly been whether entrepreneurship education can raise the students' intentions to pursue a career as self-employed (Krueger \& Brazeal, 1994; Kolvereid \& Isaksen, 2006). It is first and foremost the Theory of Planned Behaviour (Ajzen, 1991), which is based on the FishbeinAjzen models (Fishbein \& Ajzen, 1975), that has been applied (see for example Fayolle, Gailly \& Lassas-Clerc, 2006; Graevenitz, Harhoff \& Weber, 2010; Krueger, 1993; Krueger \& Carsrud, 1993; Peterman \& Kennedy, 2003; Souitaris, Zerbinati \& Al-Laham, 2007; Tkachev \& Kolvereid, 1999). To use intentions as unit of measurement when assessing outcomes of entrepreneurship educations makes good sense, as it is a good predictor of behaviour, such as the act of starting up a new business which typically exhibits a significant time-lag (Bird, 1988; Boyd \& Vozikis, 1994; Lent, Brown \& Hackett, 1994). From a normative point of view, however, it is hard to argue that the learning goals of university education should concern this type of outcome (Karlsson \& Moberg, forthcoming). The main purpose of education is to enhance the students' knowledge within a particular field and equip them with relevant skills (Biggs \& Tang, 2007), not to enhance intentions. This makes the theory of selfefficacy (Bandura, 1977; 1997) more appropriate when it comes to outcome evaluation of educational programs.

Self-efficacy, that is "people's judgments of their capabilities to organize and execute courses of action required to attain designated types of performances to the extent that their level of motivation, affective states and actions are based more on what they believe than on what is objectively true" (Bandura, 1986, p. 391), has been widely applied within many fields to assess the impact of different programmes (Mauer et al., 2009). It has become popular within the field of entrepreneurship education because when it comes to the act of starting up a new venture the individuals' perception of their abilities has a greater effect than whether 
they actually have these abilities (Krueger \& Dickson, 1994). Task-specific self-efficacy which in our case is entrepreneurial self-efficacy - has proven to be a potent predictor of intention and behaviour, and provides us with a useful bridge between the effects of education and its impact on behaviour (Boyd \& Vozikis, 1994; Mauer et al., 2009). In the next section I will discuss different types of ESE-scales and why there is a need for the development of a new scale.

\section{Entrepreneurial Self-Efficacy Scales}

Many validated multidimensional ESE-scales have been applied empirically with good results. According to Mauer et al. (2009) the scales developed by Chen, Greene and Crick (1998) (henceforth the Chen-scale) and DeNoble, Jung and Ehrlich (1999) (henceforth the DeNoble-scale), are the most recognized ones within the field. The latest addition to the field published in an academic journal is the impressive work by McGee, Peterson, Mueller and Sequeira (2009) (henceforth the McGee-scale). As opposed to the other scales, this scale was developed by using confirmatory factor analysis, and should thus be suitable for structural equation modelling. It also has a firm theoretical foundation that is structured in line with Stevenson, Roberts and Grousbeck's (1985) theory of different stages of the entrepreneurial project. Unfortunately, the multidimensionality of this scale can be questioned as the constructs show poor discriminant validity. One of the constructs has a positive correlation of .94 and .91 with two other construct (see also Stromayer, Miller, DeMartino \& Murthy, 2012, for a discussion about this).

When these scales are compared, it is clear that they are fairly heterogeneous. This makes the concept of ESE somewhat unreliable, or at least empirically underdeveloped, as the scales should be measures of the same thing. The DeNoble-scale was developed as a response 
to the poor predictive validity of the Chen-scale, but its multidimensionality is also questionable and often it is used as a single dimension (cf. Fitzsimmons \& Douglas, 2011).

Another serious problem that all these scales have in common is that they use a wording that is highly biased towards business and start-up activities. The scales all include complex and discipline-specific questions such as: How much confidence do you have in your ability to develop contingency plans to backfill key technical staff (DeNoble et al., 1999); establish position in product markets (Chen et al., 1998); determine a competitive price for a new product or service (McGee et al., 2009). Although these skills can be regarded as important to venture creators, it is hard to see that for example students are able to evaluate their ability regarding this in a meaningful way, especially non-business students. This is a typical problem, i.e. the use of technical jargon, that many scales experience (Spector, 1992; Peterson, 2000). For ESE scales, the use of technical jargon is critical due to, at least, three reasons.

1) The growing demand of programme evaluations within entrepreneurship education has made the use of propensity score matching and control groups very common. In order to measure the effects of a treatment, we want to make sure that the effects are caused by this treatment and not by other external effects, such as for example institutional change, changes in the economy or simply the maturity process of young students (Mohr, 1995). In order to do this, we need to use a control group, that is, a group that has very similar characteristics as the experiment group, except that they are not the target of the treatment, which in our case would be entrepreneurship education. This group cannot be expected to understand the technical jargon of entrepreneurship, especially not if it is biased towards business and start-up activities. 
2) The second reason has to do with the learning of students who are subject to a specific treatment. In programme evaluations with longitudinal design, it should be expected that the students in the treatment group will develop an understanding of the technical jargon of the field (Shepherd, 2004). The next time they take the test it will be difficult to assert if the effects of the treatment are real or just a result of increased understanding of the field's terminology. This might especially be the case when it comes to entrepreneurship students outside of the business school, as they often do not have any previous experience of the language used within the field.

3) The third issue has to do with the goals of entrepreneurship education. As demonstrated in the theory discussion above, many researchers (e.g. Gibb, 2002; Hannon, 2006; Sarasvathy \& Venkataraman, 2011) argue that entrepreneurship education has many positive effects other than an increased number of start-ups. These researchers argue that the changes in society and in the economy during the last decade make the capacity to act entrepreneurial a necessary ability for all individuals. The effects of entrepreneurship education should also be measurable when it comes to students who choose to pursue a career as employees and engage in strategic and corporate entrepreneurship. Examples of this might be to assess if the students experience higher income levels, get positions with more responsibility, or work within sectors with higher innovation activities (for examples of this, see Charney \& Libecap, 2000). This learning would not be captured by a scale that only focuses on venture creation activities. We can, thus, clearly see that there are at least three good reasons why an ESE-scale with a neutral wording is needed.

\section{The Development of an ESE-Scale with a Neutral Wording}


The first step in developing a new ESE-scale was to review the literature on existing scales in detail. The goal of this detailed review was to identify what skill-sets the previous scales have been focusing on. When the three scales presented above were compared, it was clear that the theoretical foundation of the McGee-scale was strongest. The constructs in the McGee-scale are based on skills that are needed in different stages of the entrepreneurial project and, thus, function well with the development process of an educational programme. They are also more general compared to the other two that include very specific constructs such as "Establish core purpose" (DeNoble et al., 1999) and "Marketing" (Chen et al., 1998). It was, thus, decided that the McGee-scale should be used as the base for comparing what skill-sets the scales are focusing on. The three scales have a significant overlap in focus, and many items were fairly similar. The main difference between the McGee-scale and the two other scales is that it lacks a construct which focus on uncertainty. In table 1 below, the focus of the three ESE scales is presented.

\section{[Insert table 1 here]}

It is clear that a new scale based on a comparison of the three scales should include the following six constructs: Creativity; Planning/Management; Marshalling; Human Resource Management; Financial Literacy and Managing Ambiguity. An initial item-pool based on the items in the three scales belonging to these six constructs was constructed. Programme leaders of six master programmes in entrepreneurship were invited in this development phase to give feedback on the scale. The importance of the Human Resource Management construct was questioned. None of the programme leaders believed that students' self-efficacy regarding HR-skills had any impact on their start-up behaviour, and accordingly none of them focused 
on teaching these types of skills in their programmes. An explanation as to why two of the scales have a strong focus on HR-skills might be that they have been based on what experienced entrepreneurs see as important skills. We thus decided to omit items related to the HR-construct as it could be questioned whether this type of skills influences start-up activities more than the decision to pursue a career within established organizations. There were now 25 items left in the item-pool, and four new ones were added on the recommendation of the educators.

The five constructs and the 29 items included in the scale are well in line with the different views of entrepreneurship education presented earlier in this paper. The "classic" discovery view of entrepreneurship with its roots within strategic management has a strong focus on planning skills and financial knowledge (Honig, 2004), whereas the newer creation view has a focus on marshalling skills and how to manage ambiguity (Korsgaard, 2009). Creativity is seen as equally important by both of these perspectives (Alvarez and Barney, 2010). We can also see that the skill-sets covered by the constructs are well in line with the more synthetic view of Kuratko and Hodgetts (2004):

Entrepreneurship is a dynamic process of vision, change, and creation. It requires an application of energy and passion towards the creation and implementation of new ideas and creative solutions. Essential ingredients include the willingness to take calculated risks - in terms of time, equity, or career; the ability to formulate an effective venture team; the creative skill to marshal needed resources; and fundamental skill of building solid business plan; and finally, the vision to recognize opportunity where others see chaos, contradiction, and confusion (Kuratko \& Hodgetts, 2004; 30).

\section{Testing the Scale}


In August, 2011, curricula designers of six master programmes with a focus on entrepreneurship at three different universities in Denmark and one university in Sweden agreed to participate in the survey. Four of these programmes were located at business schools, one at a technical university and one at a university where the programme targeted students of the humanities. They were asked to suggest other master programmes that could function as suitable control groups to their students. In order to decide if these programmes were suitable for the study, the author of this book chapter interviewed the programme leaders about their curricula design and the characteristics of the students. Out of eight recommended programmes, six were included in the survey. In the beginning of the programme's first semester, in September 2011, the questionnaires were distributed in hard copy to the students of the twelve programmes. 445 hard copies were distributed which in total generated 434 usable responses. In table 2 the demographic characteristics of the sample as well as educational background, work experience and entrepreneurial experience are presented.

\section{[Insert table 2 here]}

The sample is evenly distributed regarding treatment (52\%) and control groups (48\%) as well as gender (48.5\% females). There is, however, a strong dominance of business schools students (68\%), compared to engineering students (13\%) and university students (19\%), which somewhat decreases the generalizability of the results. The number of exchange students (38\%) does, however, increase the generalizability, as they lower the contextual-bias of the sample. The amount of work experience is also fairly high, but this is typical for a Danish sample, as Danish youth can start to work part-time at the age of thirteen, and most students have a part-time job next to their studies. What is extraordinary in connection with 
this sample is the amount of entrepreneurial experience. $24 \%$ of the students have operated a business in the past, $14.5 \%$ are operating a business today and $29 \%$ are actively trying to set up their venture. This overrepresentation of entrepreneurial experience is, however, very common in programme assessments targeting entrepreneurship education (Martin, McNally \& Kay, forthcoming).

\section{The Design of the Survey}

Besides the 29 ESE-items, a three item Entrepreneurial Attitude scale from McGee et al. (2009) was included. This scale is structured as a dichotomous scale with items such as "In general, starting a business is Worthless=1, Worthwhile=7. An Entrepreneurial Activity list with 19 items, developed by Paul Reynolds, but first published in a scientific journal by Alsos and Kolvereid (1998) was also included. Example items in this scale are "Have you initiated or completed any of the following activities: Organized a start-up team; Looked for facilities/equipment; Developed a product/service". This list was used to decide if the students were nascent entrepreneurs. Students who replied positively to the question "Are you for the moment trying to start a business for real as opposed to just evaluating a business idea out of interest or as an academic exercise" and also checked two or more of the 19 entrepreneurial activities, were coded as nascent entrepreneurs. As can be seen in table 2 above, students were also asked to indicate if they had "alone or together with others operated a business in the past" or if they are "currently, alone or together with others, operating a business today". If a student replied yes to any of these questions, they were coded as belonging to the group with entrepreneurial experience. In addition, several questions about background such as age, gender, education, and work experience, which also is presented in table 2 above, was 
included. The 29 items in the ESE-scale were measured on a 7-point Likert scale, ranging from Do not agree (=1) to Agree (=7).

\section{Reliability and Construct Validity}

A Principle components factor analysis with Varimax rotation was conducted. Five factors had an Eigen-value greater than $1(10.38,2.30,1.55,1.23,1.06)$ demonstrating that five was the suitable number of factors when all 29 items were included. These five factors explained $57 \%$ of the total variance. Loadings of .50 or greater were considered as meaningful which led to eight items (q.1, q.8, q.15, q.19, q.20, q.24, q.28, q.32, see Appendix A) being left out, in the first analysis. In the second analysis another item (q.23) failed to reach the .50 cut. Twenty items loaded greater than .50 on five factors which all demonstrated Eigen-values greater than $1(6.89,2.21,1.50,1.09,1.00)$ explaining in total $63 \%$ of the variance.

In order to test the robustness of the results the factor analysis was performed again, but this time with oblique rotation instead of orthogonal. The oblique rotation allows for multiple loadings on different factors and is thus suitable for a scale with multiple dimensions (DeVellis, 2012). In the first factor analysis, the same eight items that failed to reach the .50 cut-off point in the factor analysis with orthogonal rotation, also failed to reach the cut-off point here, but also an additional item (q.14), failed to reach this value. As its loading was very close (.49) to the cut-off point, it was still included in the second analysis. In the second analysis item q.14 raised its loading to .57 , whereas item q.23 dropped below .50 . The two rotation techniques thus generated the same twenty items with factor-loadings greater than .50 , which demonstrates that the data is robust. A Kaiser-Meyer-Olkin (KMO) test was performed in order to measure the sampling adequacy and assess if there were any items demonstrating too high multicollinearity. The results showed that each item had a KMO 
statistic above the recommended threshold of .60 (Hair, Black, Babin, Anderson \& Tatham, 2006) and that the KMO overall statistic was .86.

Next step was to determine the reliability and internal validity of the five constructs. Cronbach's alpha tests were performed in order to assess the internal validity of each construct. In table 3 below the estimates are presented, both aggregated for all the 434 students in our sample and separately for the control and the treatment groups.

\section{[Insert table 3 here]}

In general, the constructs show sufficiently high Cronbach's alpha estimates, but we can see that the Marshalling constructs drop just below .70, which is usually regarded as the critical estimate (Nunnally, 1978). However, for a new scale with constructs including few items, estimates above .60 can be viewed as acceptable (Forza, 2002). The results do, however, indicate that there is still room for improvement of the Marshalling construct. The coefficient alpha reliability estimates are very similar between the two groups, which indicate that all respondents have understood the questions in the same way, and it can therefore be concluded that the scale has a neutral wording.

In order to test the construct validity of our scale a so called known-groups validation (DeVellis, 2012) was performed. The sample was divided into two groups. The first group included students that have operated a business; are operating a business or are trying to set up a business $(\mathrm{N}=175)$, and a baseline group included the rest of the students $(\mathrm{N}=259)$. $t$-Tests were used in order to establish if there was significant difference in mean scores between the two groups. The students with entrepreneurial experience had significantly higher mean- 
values in 17 out of the 20 items. The planning items show poor construct validity as the students with entrepreneurial experience only have significantly higher mean-value in one of the three items. In an absolute sense, however, the students with entrepreneurial experience showed higher mean-values in all 20 items. In table 4, the results of the $t$-Tests are presented as well as the factor-loadings of the Principle components factor analysis with oblique rotation, and the coefficient alpha reliability estimates.

\section{[Insert table 4 here]}

\section{Confirmatory Factor Analysis}

Confirmatory factor analysis (CFA) has grown in popularity within the social sciences as it allows for a greater number of analytical procedures than exploratory factor analysis (EFA) (March, Muthén, Asparouhov, Lüdtke, Robitzsch \& Morin, 2009). With CFA it is possible to conduct multi-group analysis, compute modification indices, and correlate unique variances among observed variables (Stromayer et al., forthcoming). It should, however, be noted that CFA tends to over-factor and generates better fit indices if a greater number of factors are used than can been found in the EFA (DeVellis, 2012). It can thus be seen as a robustness test if the number of factors found in the EFA provides a good fit in the CFA.

A confirmatory factor analysis including the 20 items was performed. Maximum likelihood (ML) was used as the estimator. The 5-factor model met Bentler's (1990) criteria for good fit indices with a Comparative Fit Index (CFI) greater than .90, a Root Mean Square Error of Approximation (RMSEA) below .06 and a Standardized Root Mean Square Residual (SRMR) below .08 (CFI=.92, RMSEA=.06 [.057-.071], SRMR=.06). All items loaded 
significantly on their constructs $(p<.001)$, with weights ranging from .54 to .93 . There was, however, a relatively high correlation between the constructs. The Managing Ambiguity constructs correlate highly (.73) with two other constructs (Creativity and Marshalling) ${ }^{1}$. A 3factor model was thus tested, where the items in the Creativity, Marshalling and Managing Ambiguity constructs were combined in one construct. The 5-factor model produced a significantly better fit $\left(\chi^{2}\right.$ difference $\left.=249.6, \mathrm{df}=7, p<.001\right)$ than the 3 -factor model $(\mathrm{CFI}=.85$, RMSEA=.09 [.079-.092], SRMR=.07). In table 5 below the correlations between the five constructs are presented.

\section{[Insert table 5 here]}

The results support convergent validity as all items had significant loadings above .50 on their constructs, and discriminant validity as none of the constructs correlated above .85 with another construct (Brown, 2006). In the next section, further convergent and discriminant as well as nomological validity tests will be presented.

\section{Convergent, Discriminant and Nomological validity}

In order to test the convergent, discriminant and nomological validity of the scale, two additional constructs were included in the model: Entrepreneurial Behaviour and Entrepreneurial Attitudes. Entrepreneurial attitudes have been found to be high among individuals with high levels of ESE (McGee et al., 2009). There should, thus, be a

\footnotetext{
${ }^{1}$ It should, however, be noted that the correlation between these constructs are far below the .91 and .94 correlations in the McGee-scale.
} 
significantly positive correlation between the five constructs in the ESE-scale and entrepreneurial attitudes in order to demonstrate convergent validity; but not in such great magnitude so as to indicate construct redundancy and thus fail to demonstrate discriminant validity. In table 6 below, the correlation between entrepreneurial attitudes and the five ESEconstructs are presented.

\section{[Insert table 6 here]}

The results in table 6 demonstrate support to the convergent and discriminant validity of the items in the ESE-scale. All five ESE-constructs have a positive correlation with entrepreneurial attitudes on a $\mathrm{p}<.01$ significance level, but none of them correlate at a level above 40 .

In order to better understand the nomological validity of the scale, a structural equation model (SEM), in which the five ESE-constructs and the Entrepreneurial Attitudes construct were set to explain Entrepreneurial Behaviours of the students in the sample, was constructed. The Entrepreneurial Behaviour construct was constructed by three binominal items to which students could reply yes and no (q62. Have you, alone or together with others, started a business in the past? q63. Do you, by yourself or together with others, operate a business today? q65. Are you trying to start a business for real as opposed to just evaluating an idea out of interest or as part of an academic exercise?). In table 7 the correlation-matrix of the whole model is presented and in figure 1 the results of the relationship between the five ESE-constructs and the Entrepreneurial Attitude construct, to Entrepreneurial Behaviour is presented. 
[Insert Table 7 here]

[Insert Figure 1 here]

Because the Entrepreneurial Behaviour variables are categorical, a mean-adjusted weighed least square (WLSM) estimator was used. This generated an acceptable model fit with a CFI=.94; RMSEA=.07 [.064-.074], and Weighted Root Mean Square Residual (WRMR) = .96 (SRNR and Chi-square cannot be calculated with a WLSM-estimator).

The construct with the largest effect on Entrepreneurial Behaviours is Managing Ambiguity, closely followed by Financial Literacy and Entrepreneurial Attitudes. Marshalling and Creativity come out as insignificant, whereas Planning comes out with a significant negative effect on Entrepreneurial Behaviours.

\section{Discussion and Implications}

The results of the survey demonstrate that the multidimensionality of an ESE-scale is of great importance if we want to understand entrepreneurial self-efficacy in a nuanced manner. Although the items of the five constructs in the scale show both convergent and disciminant validity when compared to entrepreneurial attitudes, the effect of the five dimensions on entrepreneurial behaviours is divergent. Out of the five dimensions, only the Financial Literacy and Managing Ambiguity skill-sets come out as important in explaining entrepreneurial behaviours. The significantly negative effect of students' perceived ability to 
plan is a somewhat puzzling result. Planning skills is of central importance in the three validated ESE-scales that lie as a foundation to this newly constructed scale. This result does, however, lend support to more recent theories about entrepreneurship such as the entrepreneurial effectuation logic (Sarasvathy, 2001) and the creation view (Alvarez \& Barney, 2007). Proponents of these views argue that the ability to adapt to change and leverage ambiguity is of much greater importance than the ability to predict and plan ahead in order to avoid risk and uncertainty. On the other hand, the importance of financial literacy lends support to the more classic view of entrepreneurship as belonging to the field of management (Honig, 2004).

According to the neo-Austrian researchers Foss and Klein (2012), who propagate a more synthetic view of entrepreneurship, the core of entrepreneurship lies in the entrepreneur's ability to practice her judgement in order to make correct decisions of how to allocate and invest resources under true uncertainty. This implies that the most important entrepreneurial ability is the capacity to manage ambiguity, but in order to make sense of ambiguity and make correct decisions about resource allocation the entrepreneur needs a high level of financial literacy. Their view of entrepreneurial activities is, however, not limited to new venture creation, as it can be seen to be just as entrepreneurial to engage in strategic and corporate entrepreneurship, or as a venture capitalist (Foss \& Klein, 2012).

There are many research streams within the field of entrepreneurship that share Foss and Klein's view that entrepreneurship should be understood in a broader sense (cf. Gibb, 2011; Stayaert \& Katz, 2007; Rae, 2007). In my validation tests of the scale I did, however, choose to focus only on the most narrow definition of entrepreneurship, i.e. as the act of creating a new venture (Gartner, 1989); because this can be seen as the strongest test for a scale that wishes to explain entrepreneurial behaviours (McGee et al., 2009). Because the items in this scale are more neutral in their wording than previous ESE-scales, this validation- 
test is of great importance, as it could be expected that the increased reliability this neutral wording leads to comes at a cost of explanation power. The results of my survey show that this might be the case when it comes to the Creativity and Marshalling constructs, as their effect on entrepreneurial behaviours came out as insignificant. It is hard to argue that these abilities are not important for an entrepreneur, but it might be the case that established organisations have begun to value these abilities to such an extent that they today belong to both an employability skill-set and a venture creation skill-set.

In order to test the validity of the scale regarding other types of activities that can be viewed as entrepreneurial, it should be tested on different samples such as practicing project managers and CEOs. Combined with a measure of the organisations' Entrepreneurial Orientation (EO) as well as innovation activity, it could be tested if ESE is just as important to corporate and strategic entrepreneurship, as it is to new venture creation. An alternative could be to perform longitudinal research on educational programmes and follow up on the students in order to analyse how they perform on the work market. This would allow us to compare different effects of different educational designs. An example would be to compare entrepreneurship programmes that build on the discovery view with entrepreneurship programmes that are more influenced by the creation view, and investigate if they have different effects on different ESE-constructs, and what effects this have on consecutive entrepreneurial behaviours.

\section{Limitations and recommendations to future research}

I have used many techniques in the design of the surveys in order to avoid sampling bias, such as including students from many different disciplines and universities, included control groups and distributed the questionnaires in hard copy. Still, replication studies are needed as 
well as tests with different samples in different countries in order to improve the generalizability of the results. Different types of entrepreneurs, such as high growth entrepreneurs and serial entrepreneurs could be a suitable sample in order to further test the validity of the scale, but also project managers, middle managers and CEOs would be an interesting sample, for testing the effects of ESE on corporate and strategic entrepreneurship. Longitudinal studies would also be needed in order to test the actual causality of ESE on entrepreneurial behaviours.

In order to test the validity and reliability of this newly constructed scale it could be an idea to make a comparison study where both this scale and one of the established scales are included in the same questionnaire. If a varied sample are included in this type of survey, it would not only allow the researcher to investigate which of the scales had the highest explanation power, but also which scale was most suitable regarding the characteristics of the respondents. The actual influence of ESE on entrepreneurial behaviour would also be more robust if it was compared to a larger scope of other latent constructs, such as entrepreneurial intentions, social capital, general self-efficacy, core self-assessment and perhaps the "big five" personality constructs.

\section{Concluding Remarks}

In this book chapter I demonstrate that there is a need for an entrepreneurial self-efficacy (ESE) scale with a neutral wording. A new ESE-scale, which is based on three established ESE-scales has been presented and the results of both an exploratory and a confirmatory factor analysis demonstrate that it has good convergent, discriminant and nomological validity. By using a covariance model to test the effect of ESE on entrepreneurial behaviours, it became evident that the multidimensionality of the scale is important, as it allow us to 
assess the impact of different skill-sets. The results in my study support the more recent theories of entrepreneurship, such as the creation view and the entrepreneurial effectuation logic, as the students' perceived ability to plan ahead had a significantly negative impact on entrepreneurial behaviours. The positive effect of students' perceived financial literacy and ability to manage ambiguity is well in line with the recent theory of entrepreneurship as the ability to exercise judgment under true uncertainty in order to make correct decisions on how to allocate resources, proposed by Foss and Klein (2012).

The scale was developed in order to meet the growing demand of programme evaluations which includes respondents who are not familiar with a business- and entrepreneurship specific jargon, for example educational programmes outside of the business school or when the research design is dependent on the use of control groups. The results in the surveys demonstrate that the students, regardless of disciplinary background, understand the questions in the same way because the internal coefficient estimates are similar in both the treatment group and in the control group. In order to test the causality of ESE's effect on entrepreneurial behaviours, longitudinal studies are required in which the students of different educational programmes are followed over time. This would also allow for a comparison of the effects of different programme designs.

\section{References}

Ajzen, I. 1991. The theory of planned behavior. Organizational behavior and human decision processes, 50 : 179-211.

Alsos, G.A. \& Kolvereid, L. 1998. The business gestation process of novice, serial, and parallel business founders. Entrepreneurship Theory and Practice 22: 101-114.

Alvarez, S.A., \& Barney, J.B. 2007. Discovery and creation: Alternative theories of entrepreneurial action. Strategic Entrepreneurship Journal, 1 (1-2): 11-26.

Alvarez, S.A., \& Barney, J.B. 2010. Entrepreneurship and epistemology: The Philosophical underpinnings of the study of entrepreneurial opportunities. The Academy of Management Annals, 4 (1): 557-583.

Alvarez, S.A., \& Barney, J.B. 2012. Discovery and creation: Complementary theories of entrepreneurship. In Alvarez, S.A, Angle, M.W., Barney, B., Foss, N.J., Klein, P.G. \& Mathews, J.A. (Eds.). Strategy \& Entrepreneurship. Lund: Lund Business Press, 1-39. 
Bandura, A. 1977. Self-efficacy: Toward a unifying theory of behavioral change. Psychological Review, 84: 191-215.

Bandura, A. 1986. Social foundations of thought and action: A social cognitive theory. Englewood Cliffs, NJ: Prentice-Hall.

Bandura, A. 1997. Self-efficacy: The exercise of control. New York: Freeman.

Barbosa, S., Gerhardt, M., \& Kickul, J. 2007. The role of cognitive style and risk preference on entrepreneurial self-efficacy and entrepreneurial intentions. Journal of Leadership \& Organizational Studies, 13(4), 86104.

Bentler, P.M. 1990. Comparative fit indices in structural models. Psychological Bulletin, 107: 238-246.

Biggs, J. and Tang, C. 2007. Teaching for quality learning at university: What student does. 3rd ed Open University Press. McGraw Hill. Berkshire.

Bird, B. 1988. Implementing entrepreneurial ideas: The case for intention. Academy of Management Review, 13(3): 442-453.

Boyd, N. \& Vozikis, G. 1994. The influence of self-efficacy on the development of entrepreneurial intentions and actions. Entrepreneurship Theory and Practice, 18(4), 63-77.

Brown, T.A. 2006. Confirmatory factor analysis for applied research. The Guilford Press.

Burgelman, R.A. 1984. Designs for corporate entrepreneurship. California Management Review. 26: 154-166

Chen, CC., Greene, P.G, \& Crick, A. 1998. Does entrepreneurial self-efficacy distinguish entrepreneurs from managers? Journal of Business Venturing, 13: 295-316.

Charney, A. \& Libecap, G. D. 2000. The Impact of entrepreneurship education: An evaluation of the Berger entrepreneurship program at the University of Arizona, 1985-1999. Final report to the Kauffman Center for Entrepreneurial Leadership.

De Noble, A.F., Jung, D., \& Ehrlich, S.B. 1999. Entrepreneurial self-efficacy: The development of a measure and its relationship to entrepreneurial action. In R.D. Reynolds, W.D. Bygrave, S. Manigart, C.M. Mason, G.D. Meyer, H.J. Sapienza (Eds.). Frontiers of entrepreneurship research (pp. 73-87). Waltham, MA: P\&R Publications Inc.

DeVillis, R.F. 2011. Scale development: Theory and applications. 3rd ed. Sage

Fayolle, A., Gailly, B. \& Lassas-Clerc, N. 2006. Assessing the impact of entrepreneurship education programmes: a new methodology. Journal of European Industrial Training, 30: 701-720.

Fishbein, M. \& Ajzen, I. 1975. Belief, attitude, intention, and behavior: An introduction to theory and research. Reading, MA: Addison-Wesley.

Forza, C. 2002. Survey research in operations management: a process-based perspective. International Journal of Operations \& Production Management, 22(2): 152-194.

Foss, N.J. \& Klein, P.G. 2012. Organizing entrepreneurial judgment: A new approach to the firm. Cambridge University Press.

Foss, N.J. \& Lyngsie, J. 2011. The Emerging strategic entrepreneurship field: Origins, key tenets, and research gaps. In: Hjorth, D. (ed.) Handbook of Organizational Entrepreneurship, Edward Elgar

Fitzsimmons \& Douglas, 2011. Interaction between feasibility and desirability in the formation of entrepreneurial intentions. Journal of Business Venturing, 26, 431-440.

Gartner, W.B. 1989. "Who is the entrepreneur?" Is the wrong question. Entrepreneurship Theory and Practice, 47-68

Gibb, A.A. 2002. Creating conducive environments for learning and entrepreneurship - living with, dealing with, creating and enjoying uncertainty and complexity. Industry and Higher Education, June 2002, 135148

Gibb, A.A., \& Hannon, P.D. 2006. Towards the entrepreneurial university? International Journal of Entrepreneurship Education, 4(1), 73-110.

Gibb, A.A. 2011. Concepts into practice: meeting the challenges of development of entrepreneurship educators around an innovative paradigm - The case of International Entrepreneurship Educators' Programme (IEEP). International Journal of Entrepreneurial Behaviour \& Research, 17 (2): 146-165

Graevenitz, G., Harhoff, D. \& Weber, R. 2010. The effects of entrepreneurship education. Journal of Economic Behavior \& Organization, 76: 90-112.

Hair, J.E., Black, W.C., Babin, B.J., Anderson, R.E., \& Tatham, R.L., 2006. Multivariate Data Analysis, 6th ed. Prentice-Hall, Upper Saddle River, NJ.

Hannon, P.D. 2006. Teaching pigeons how to dance: sense and meaning in entrepreneurship education. Education + Training, Vol. 48(5):296 - 308.

Hitt, M.A., Ireland, R.D., Camp, S.M. \& Sexton, D.L. 2001. Guest Editors, Introduction to the Special Issue. Strategic Entrepreneurship: Entrepreneurial Strategies for Wealth Creation. Strategic Management Journal. 22: 479-491.

Honig, B. 2004. Entrepreneurship education: Toward a model of contingency-based business planning. Academy of Management Learning and Education, 3(3): 258-273. 
Karlsson, $\mathrm{T} \&$ Moberg $\mathrm{K}$, forthcoming. Improving perceived entrepreneurial abilities through education: Exploratory testing of an Entrepreneurial Self Efficacy scale in a pre-post setting. The International Journal of Management Education.

Katz, J.A. 2003. The Chronology and intellectual trajectory of American entrepreneurship education 1876-1999, Journal of Business Venturing, 18 (2): 283-300.

Katz, J.A. 2008. Fully mature but not fully legitimate: A different perspective on the state of entrepreneurship education. Journal of Small Business Management, 46 (4): 550-566.

Kolvereid, L. and Isaksen, E. 2006. New business start-up and subsequent entry into self-employment. Journal of Business Venturing 21: 866-885.

Korsgaard, S. 2009. Beyond discovery: A Review of critique of the discovery view of opportunities. Academy of Management Conference. Chicago, Ill.

Krueger, N. 1993. The impact of prior entrepreneurial exposure on perceptions of new venture feasibility and desirability. Entrepreneurship Theory and Practice, 18(1): 521-530.

Krueger, N. 2009. Entrepreneurial intentions are dead: Long live entrepreneurial intentions. In: Carsrud, A.L. and Brännback, M. (Eds.). Understanding the entrepreneurial mind: Opening the black box. Dordrecht, Heidelberg, London, New York: Springer 51-72.

Krueger, N. \& Brazeal, D. 1994. Entrepreneurial potential and potential entrepreneurs. Entrepreneurship: Theory and Practice, 18: 91-104.

Krueger, N. \& Carsrud, A.L. 1993. Entrepreneurial intentions: Applying the theory of planned behavior. Entrepreneurship and Regional Development 5: 315-330.

Krueger, N. \& Dickson, P.R. 1994. How believing in ourselves increases risk taking: Self-efficacy and opportunity recognition. Decision Sciences, 25(3): 385-400.

Kuratko, D.F. 2005. The Emergence of entrepreneurship education: Development, trends, and challenges. EntrepreneurshipTheory and Practice 29(5), 577-597.

Kuratko, D.F. \& Hodgetts, R.M. 2004. Entrepreneurship: Theory, process, practice. Mason, OH: SouthWestern College Publishers.

Lent, R., Brown, S. \& Hackett, G. 1994. Toward a unifying social cognitive theory of career and academic interest, choice, and performance. Journal of Vocational Behavior, 45: 79-122.

Marsh, H. W., Muthén, B., Asparouhov, T., Lüdtke, O., Robitzsch, A., \& Morin, A. J. 2009. Exploratory structural equation modeling, integrating CFA and EFA: Application to students' evaluations of University teaching. Structural Equation Modeling, 16(3), 439-476

Martin, B.C., McNally, J.J. \& Kay, M.J. Forthcoming. Examining the formation of human capital in entrepreneurship: A meta-analysis of entrepreneurship education outcomes. Journal of Business Venturing.

Mauer, R., Neergaard, H., \& Kirketerp, A. 2009. Self-Efficacy: Conditioning the entrepreneurial mindset. In: Carsrud, A.L. and Brännback, M. (Eds.), Understanding the Entrepreneurial Mind: Opening the Black Box. Springer, Dordrecht, Heidelberg, London, New York, 233-257

McGee, J. E. M. Peterson, S.L. Mueller \& J.M. Sequeira. 2009. Entrepreneurial self-efficacy: Refining the measure. Entrepreneurship Theory and Practice, 33(4).

Mohr, L.B. 1995. Impact Analysis for Program Evaluation. Thousand Oaks, CA: Sage Publications

Neck, H.M., and Greene, P.G. 2011. Entrepreneurship education: Known worlds and new frontiers. Journal of Small Business Management, Vol. 49(1): 55-70.

Nunnally, J.C. 1978. Psychometric Theory, 2nd ed. McGraw-Hill, New York.

Peterman, N. and Kennedy, J. 2003. Enterprise education: influencing students' perceptions of entrepreneurship. Entrepreneurship Theory and Practice, (28): 129-144.

Peterson, R. A. 2000. Constructing effective questionnaires. Thousand Oaks, CA: Sage.

Rae, D. 2007.Connecting enterprise and graduate employability: Challenges to the higher education culture and curriculum? Education + Training, 49 (8): 605 - 619.

Rasmussen, E. A. \& Sørheim, R. 2006. Action-based entrepreneurship education. Technovation, 26:185 -194.

Sarasvathy, S. 2001. Causation and effectuation: toward a theoretical shift from economic inevitability to entrepreneurial contingency. Academy of Management Review, 26 (2): 243-263.

Sarasvathy, S. \& Venkataraman, S. 2011. Entrepreneurship as method: Open questions for an entrepreneurial future. Entrepreneurship Theory and Practice: 113-135.

Shane, S. \& Venkataraman, S. 2000. The promise of entrepreneurship as a field of research. Academy of Management Review, 25(1): 217-228.

Shepherd, D.A. 2004. Educating entrepreneurship students about emotion and learning from failure. Academy of Management Learning and Education, 3(3): 274-287.

Souitaris, V., Zerbinati, S. \& Al-Laham, A. 2007. Do entrepreneurship programmes raise entrepreneurial intention of science and engineering students? The effect of learning, inspiration and resources. Journal of Business Venturing, 22: 566-591. 
Spector, P.E. 1992. A consideration of validity and meaning of self-report measures of job conditions. In C.L. Cooper \& I.T. Robertson (Eds.), International review of industrial and organizational psychology. (Vol. 7, pp. 123-151). New York: Wiley.

Chris Steyaert, C. \& Katz, J. 2004. Reclaiming the space of entrepreneurship in society: geographical, discursive and social dimensions, Entrepreneurship \& Regional Development, 16:3, 179-196

Stevenson H.H., \& Jarillo, J.C. 1990. A paradigm of entrepreneurship: Entrepreneurial management. Strategic Management Journal, 11, 17-27

Stevenson, H.H., Roberts, M.J., \& Grousbeck, H.I. 1985. New business ventures and the entrepreneur. Burr Ridge, IL: Richard D. Irwin.

Stromayer, W.R., Miller, J.W., DeMartino R., \& Murthy, R. 2012. My CFA Failed...Now What Should I Do? Modeling Complex Measurement Instruments and Using Exploratory Structural Equation Modeling. Working paper, Fisher College of Business

Tkachev, A. \& Kolvereid, L. 1999. Self-employment intentions among Russian students. Entrepreneurship \& Regional Development, 11: 269-280.

Zahra, S.A. 1991. Predictors and financial outcomes of corporate entrepreneurship: An exploratory study. Journal of Business Venturing. 14: 451-478.

Zhao, H., Seibert, C., \& Hills, C. 2005. The mediating role of self-efficacy in the development of entrepreneurial intentions. Journal of Applied Psychology, 90(2), 1265-1272.

Tables and Figures

\begin{tabular}{|l|l|l|l|}
\hline Focus: & Chen et al. (1998) & De Noble et al. (1999) & McGee et al. (2009) \\
\hline Search/Creativity & Strong & Strong & Strong \\
\hline Planning/Management & Strong & Strong & Strong \\
\hline Marshalling & No & Strong & Strong \\
\hline Human Resources & Weak & Strong & Strong \\
\hline Financial Literacy & Strong & Weak & Strong \\
\hline Marketing & Strong & No & Weak \\
\hline Managing Ambiguity & Strong & Strong & No \\
\hline
\end{tabular}

Table 1: A comparison of the focus in three ESE-scales

\begin{tabular}{|lr|}
\hline The total number of respondents & 445 \\
The total number of respondents used in the analysis & 434 \\
\hline Descriptive statistic of the 434 respondents in the analysis & $51.5 \%$ \\
Gender & $48.6 \%$ \\
$-\quad$ Men & $n=227$ \\
- Women & $n=207$ \\
Treatment group & 25.46 \\
Control group & \\
Age (mean) & \\
\end{tabular}




\begin{tabular}{|lr|}
\hline Exchange students & $38.2 \%$ \\
Have close family members (parents, siblings, uncles/aunts) who are self-employed & $58.7 \%$ \\
Have taken a course or training program that focuses on entrepreneurship / Self- & \\
employment in the past & $34.7 \%$ \\
Have participated in an extra-curricular activity that focuses on entrepreneurship / Self- \\
employment & $31.0 \%$ \\
& \\
Part-time work experience (mean) & $5.8 \mathrm{y}$ \\
Full-time work experience (mean) & $2.2 \mathrm{y}$ \\
Educational background (mean) & $16.4 \mathrm{y}$ \\
Have alone or together with others, started a business in the past & $23.8 \%$ \\
Are today by themselves or together with others, operate a business & $14.6 \%$ \\
\hline
\end{tabular}

Table 2: Descriptive statistics of the respondents included in the analysis

\begin{tabular}{|l|l|l|l|}
\hline Construct & $\begin{array}{l}\text { Treatment } \\
\text { group } \mathbf{n = 2 2 7}\end{array}$ & $\begin{array}{l}\text { Control group } \\
\mathbf{n = 2 0 7}\end{array}$ & $\begin{array}{l}\text { All } \\
\mathbf{n}=\mathbf{4 3 4}\end{array}$ \\
\hline Creativity & .84 & .84 & .85 \\
\hline Planning & .70 & .73 & .71 \\
\hline Marshalling & .67 & .67 & .67 \\
\hline Managing Ambiguity & .77 & .76 & .77 \\
\hline Financial Literacy & .88 & .80 & .85 \\
\hline
\end{tabular}

Table 3: The convergent construct validity for the five ESE constructs and the Entrepreneurial Attitudes and Entrepreneurial Intentions constructs.

\begin{tabular}{|c|c|c|c|c|c|}
\hline & & $\begin{array}{l}\text { Factor } \\
\text { Loading }\end{array}$ & t-value & p-value & Difference \\
\hline & Creativity (Cronbach's ó .85) & & & & \\
\hline q. 2 & Identify ways to combine resources in new ways to achieve & .53 & 5.18 & .00 & .54 \\
\hline q.6 & Brainstorm (come up with) new ideas & .80 & 5.19 & .00 & .64 \\
\hline q.26 & Think outside the box & .85 & 6.12 & .00 & .75 \\
\hline q.29 & Identify opportunities for new ways to conduct activities & .76 & 5.52 & .00 & .61 \\
\hline \multirow[t]{2}{*}{ q.31 } & $\begin{array}{l}\text { Identify creative ways to get things done with limited } \\
\text { resources }\end{array}$ & .81 & 3.73 & .00 & .43 \\
\hline & Planning (Cronbach's ó .71) & & & & \\
\hline q.4 & Manage time in projects & .87 & .02 & .49 & .00 \\
\hline q.17 & Set and achieve project goals & .67 & 1.15 & .13 & .12 \\
\hline \multirow[t]{2}{*}{ q.22 } & Design an effective project plan to achieve goals & .66 & 3.04 & .00 & .33 \\
\hline & Marshalling (Cronbach's á.67) & & & & \\
\hline q.7 & $\begin{array}{l}\text { Put together the right group/team in order to solve a } \\
\text { specific problem }\end{array}$ & .51 & 3.93 & .00 & .46 \\
\hline q.10 & Form partnerships in order to achieve goals & .69 & 3.36 & .00 & .43 \\
\hline \multirow[t]{2}{*}{ q.16 } & $\begin{array}{l}\text { Network (i.e. make contact with and exchange information } \\
\text { with others) }\end{array}$ & .78 & 3.91 & .00 & .51 \\
\hline & Managing Ambiguity (Cronbach's á .77) & & & & \\
\hline q.3 & $\begin{array}{l}\text { Improvise when I do not know what the right } \\
\text { action/decision might be in a problematic situation }\end{array}$ & .67 & 3.28 & .00 & .38 \\
\hline$q .5$ & Tolerate unexpected change & .84 & 4.28 & .00 & .50 \\
\hline q.14 & Persist in the face of setbacks & .57 & 4.02 & .00 & .46 \\
\hline q.21 & Manage uncertainty in projects and processes & .50 & 4.50 & .00 & .49 \\
\hline q.25 & Work productively under continuous stress, pressure and & .72 & 3.72 & .00 & .42 \\
\hline
\end{tabular}


conflict

\section{Financial Literacy (Cronbach's à .85)}

q.9

Read and interpret financial statements

.94

3.14

.92

3.67

.00

.65

1.33

q.27

Control costs for projects

3.32

.00 .45

q.30

.75

.00

Table 4: Mean difference between students with entrepreneurial background and the base-line group

\begin{tabular}{llll}
\hline & & & \\
Planning & $<->$ & Creativity & .47 \\
Planning & $<->$ & Marshalling & .71 \\
Planning & $<->$ & Managing Ambiguity & .66 \\
Planning & $<->$ & Financial Literacy & .50 \\
Creativity & $<->$ & Marshalling & .66 \\
Creativity & $<->$ & Managing Ambiguity & .73 \\
Creativity & $<->$ & Financial Literacy & .35 \\
Marshalling & $<->$ & Managing Ambiguity & .73 \\
Marshalling & $<-->$ & Financial Literacy & .53 \\
Managing Ambiguity & $<->$ & Financial Literacy & .43 \\
& & & \\
\hline & & &
\end{tabular}

All correlations are significant on a $p<.001$

Estimator: Maximum Likelihood (ML)

$\mathrm{CFI}=.92 \mathrm{TFI}=.934, \quad \mathrm{SRMR}=.058$

RMSEA $=.064(.057-.071)$

Table 5: Correlation between constructs derived through CFA 


\begin{tabular}{lcll}
\hline Creativity & $<->$ & Attitudes & .38 \\
Planning & $<->$ & Attitudes & .79 \\
Marshalling & $<->$ & Attitudes & .53 \\
Managing Ambiguity & $<->$ & Attitudes & .38 \\
Financial Literacy & $<->$ & Attitudes & .23 \\
& & & \\
\hline
\end{tabular}

All correlations are significant on a $p<.01$

Estimator: Mean-adjusted weighed least square (WLSM)

$\mathrm{CFI}=.94 \quad \mathrm{TFI}=.93 \quad$ WRMR $=.959 \quad \mathrm{RMSEA}=.069(.064-.074)$

Table 6: Correlation between the five ESE-constructs and entrepreneurial attitudes 
Table 7

\section{Correlation-matrix for Entrepreneurial Behaviour, Entrepreneurial Attitudes and the five ESE constructs}

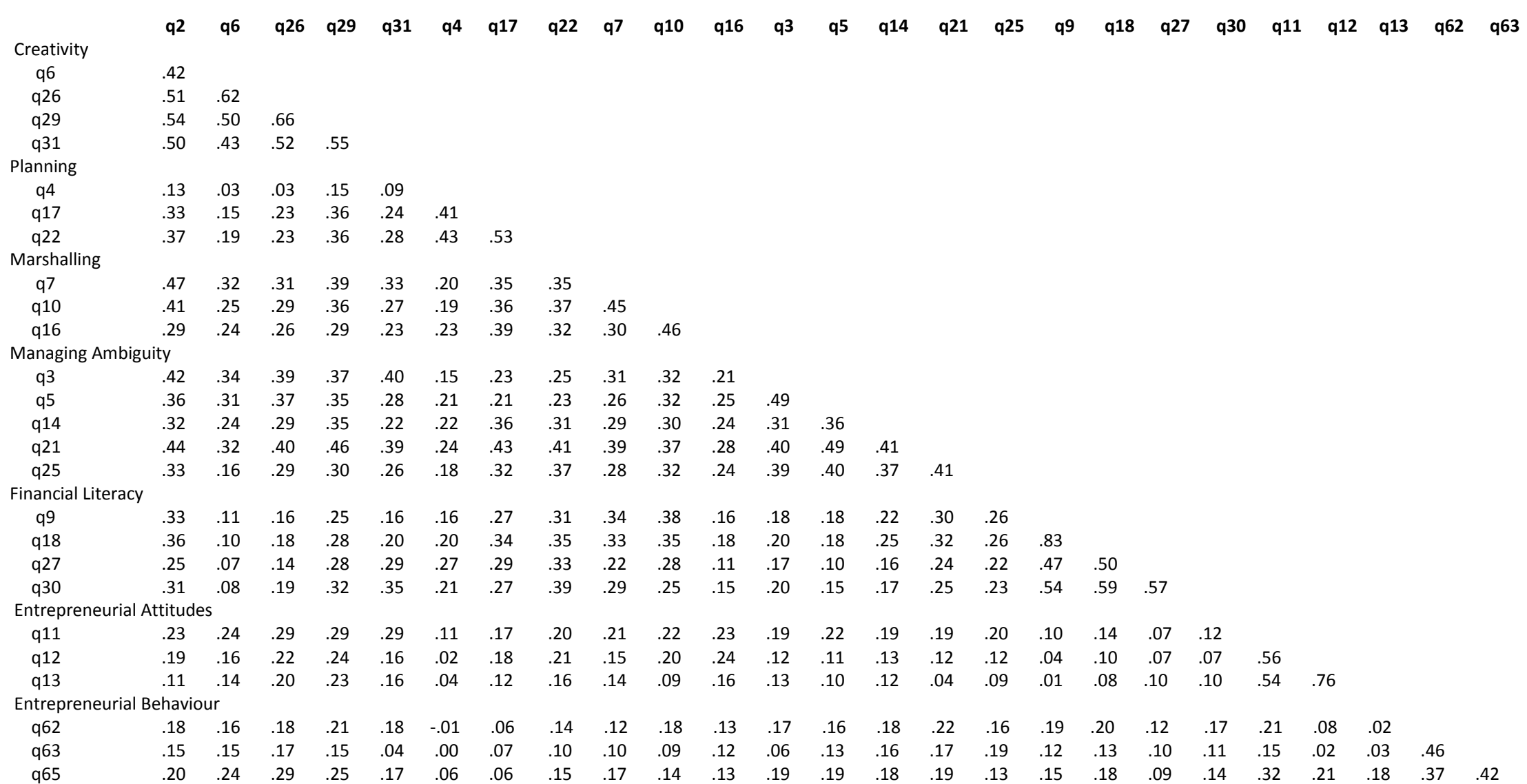

All Pearson product moment correlations greater than .09 are statistically significant at $p<.05$ 


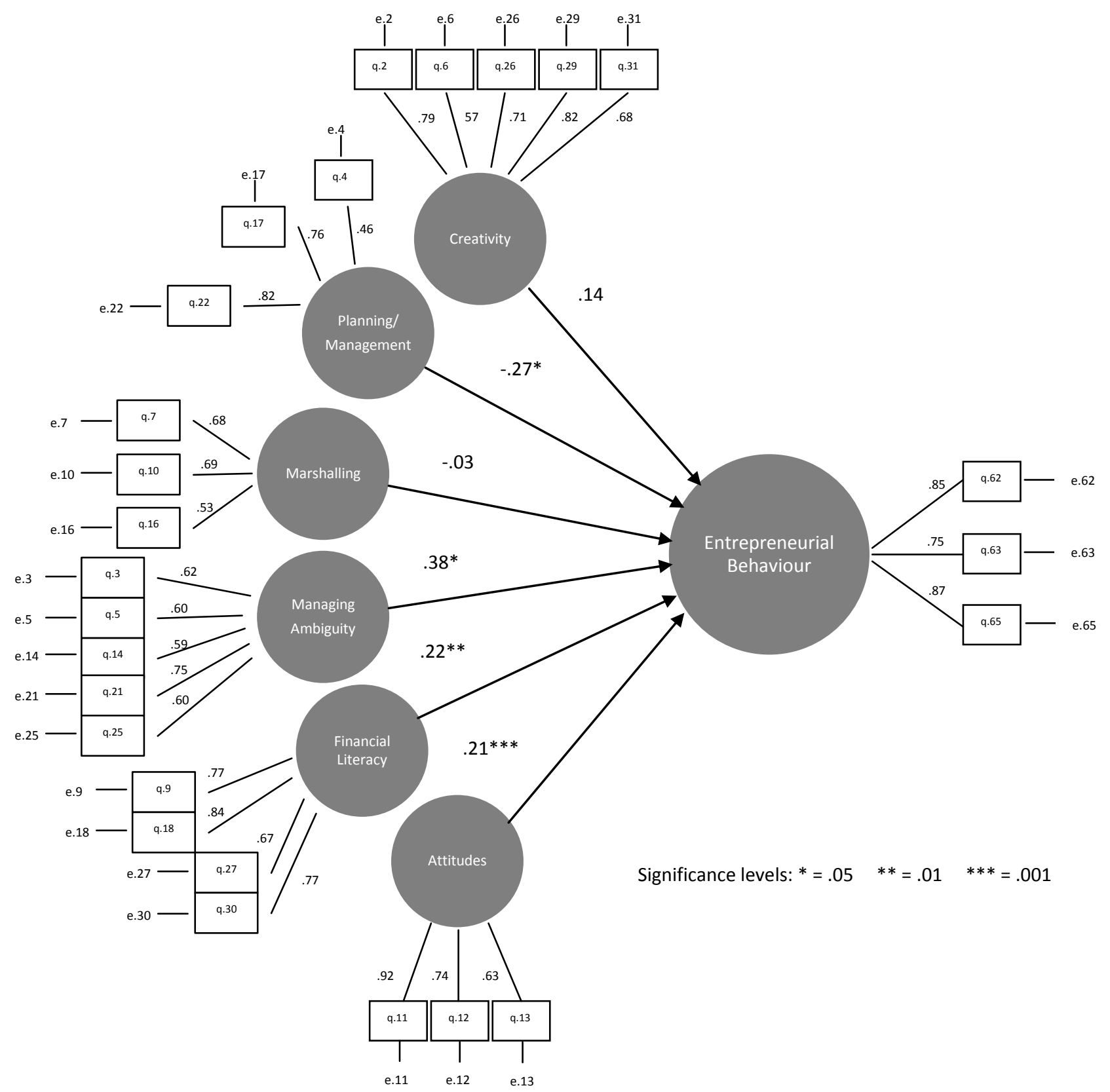

Figure 1: The effect of the five ESE-constructs and entrepreneurial attitudes on entrepreneurial behaviour 


\section{Appendix A}

The original 29 items derived from the three ESE scales developed by Chen et al. (1998), DeNoble et al. (1999) and McGee et al. (2009).

\begin{tabular}{|c|c|}
\hline Search/Creativity & Scale(s) \\
\hline 2. Identify ways to combine resources in new ways to achieve goals & The Chen \\
\hline 6. Brainstorm (come up with) new ideas & The McGee-scale \\
\hline 26. Think outside the box & Own \\
\hline 29. Identify opportunities for new ways to conduct activities & The Chen-scale/The DeNoble-Scale \\
\hline 31. Identify creative ways to get things done with limited resources & The DeNoble-scale \\
\hline \multicolumn{2}{|l|}{ Planning/Management } \\
\hline 4. Manage time in projects & The Chen-scale \\
\hline 8. Conduct analysis for a project that aims to solve a problem & The Chen-scale \\
\hline 17. Set and achieve project goals & The McGee-scale \\
\hline 22. Design an effective project plan to achieve goals & The McGee-scale \\
\hline \multicolumn{2}{|l|}{ Marshalling } \\
\hline 1. Lead and manage a team & The DeNoble-scale \\
\hline 7. Put together the right group/team in order to solve a specific problem & The DeNoble-scale \\
\hline 10. Form partnerships in order to achieve goals & The DeNoble-scale \\
\hline 15. Identify potential sources of resources & The DeNoble-scale \\
\hline 16. Network (i.e. make contact with and exchange information with others) & The McGee-scale \\
\hline 20. Get others to identify with and believe in my visions and plans & The McGee-scale \\
\hline 24. Clearly and concisely explain verbally/in writing my ideas in everyday terms & The McGee-scale \\
\hline 32. Proactively take action and practically apply your knowledge & Own \\
\hline \multicolumn{2}{|l|}{ Managing Ambiguity } \\
\hline 3. Improvise when I do not know what the right action/decision might be in a problematic situation & Own \\
\hline 5. Tolerate unexpected change & The DeNoble-scale \\
\hline 14. Persist in face of setbacks & The DeNoble-scale \\
\hline 19. Learn from failure & Own \\
\hline 21. Manage uncertainty in projects and processes & The Chen-scale/The DeNoble-scale \\
\hline 23. Exercise flexibility in complicated situations when both means and goals are hard to establish & The DeNoble-scale \\
\hline 25. Work productively under continuous stress, pressure and conflict & The Chen-scale/The DeNoble-scale \\
\hline 28. Make decisions in uncertain situations when the outcomes are hard to predict & The Chen-scale \\
\hline \multicolumn{2}{|l|}{ Financial Knowledge } \\
\hline 9. Read and interpret financial statements & The McGee-scale \\
\hline 18. Perform financial analysis & The Chen-scale \\
\hline 27. Control costs for projects & The Chen-scale \\
\hline 30. Estimate a budget for a new project & The McGee-scale \\
\hline
\end{tabular}




\section{SMG - Working Papers \\ www.cbs.dk/smg \\ 2003}

2003-1: Nicolai J. Foss, Kenneth Husted, Snejina Michailova, and Torben Pedersen: Governing Knowledge Processes: Theoretical Foundations and Research Opportunities.

2003-2: Yves Doz, Nicolai J. Foss, Stefanie Lenway, Marjorie Lyles, Silvia Massini, Thomas P. Murtha and Torben Pedersen: Future Frontiers in International Management Research: Innovation, Knowledge Creation, and Change in Multinational Companies.

2003-3: Snejina Michailova and Kate Hutchings: The Impact of In-Groups and OutGroups on Knowledge Sharing in Russia and China CKG Working Paper.

2003-4: Nicolai J. Foss and Torben Pedersen: The MNC as a Knowledge Structure: The Roles of Knowledge Sources and Organizational Instruments in MNC Knowledge Management CKG Working Paper.

2003-5: Kirsten Foss, Nicolai J. Foss and Xosé H. Vázquez-Vicente: “Tying the Manager's Hands": How Firms Can Make Credible Commitments That Make Opportunistic Managerial Intervention Less Likely CKG Working Paper.

2003-6: Marjorie Lyles, Torben Pedersen and Bent Petersen: Knowledge Gaps: The Case of Knowledge about Foreign Entry.

2003-7: Kirsten Foss and Nicolai J. Foss: The Limits to Designed Orders: Authority under "Distributed Knowledge" CKG Working Paper.

2003-8: Jens Gammelgaard and Torben Pedersen: Internal versus External Knowledge Sourcing of Subsidiaries - An Organizational Trade-Off.

2003-9: Kate Hutchings and Snejina Michailova: Facilitating Knowledge Sharing in Russian and Chinese Subsidiaries: The Importance of Groups and Personal Networks Accepted for publication in Journal of Knowledge Management.

2003-10: Volker Mahnke, Torben Pedersen and Markus Verzin: The Impact of Knowledge Management on MNC Subsidiary Performance: the Role of Absorptive Capacity CKG Working Paper.

2003-11: Tomas Hellström and Kenneth Husted: Mapping Knowledge and Intellectual Capital in Academic Environments: A Focus Group Study Accepted for publication in Journal of Intellectual Capital CKG Working Paper.

2003-12: Nicolai J Foss: Cognition and Motivation in the Theory of the Firm: Interaction or "Never the Twain Shall Meet"? Accepted for publication in Journal des Economistes et des Etudes Humaines CKG Working Paper.

2003-13: Dana Minbaeva and Snejina Michailova: Knowledge Transfer and Expatriation Practices in MNCs: The Role of Disseminative Capacity.

2003-14: Christian Vintergaard and Kenneth Husted: Enhancing Selective Capacity Through Venture Bases. 


\section{4}

2004-1: Nicolai J. Foss: Knowledge and Organization in the Theory of the Multinational Corporation: Some Foundational Issues

2004-2: Dana B. Minbaeva: HRM Practices and MNC Knowledge Transfer

2004-3: Bo Bernhard Nielsen and Snejina Michailova: Toward a Phase-Model of Global Knowledge Management Systems in Multinational Corporations

2004-4: Kirsten Foss \& Nicolai J Foss: The Next Step in the Evolution of the RBV: Integration with Transaction Cost Economics

2004-5: Teppo Felin \& Nicolai J. Foss: Methodological Individualism and the Organizational Capabilities Approach

2004-6: Jens Gammelgaard, Kenneth Husted, Snejina Michailova: Knowledge-sharing Behavior and Post-acquisition Integration Failure

2004-7: Jens Gammelgaard: Multinational Exploration of Acquired R\&D Activities

2004-8: Christoph Dörrenbächer \& Jens Gammelgaard: Subsidiary Upgrading? Strategic Inertia in the Development of German-owned Subsidiaries in Hungary

2004-9: Kirsten Foss \& Nicolai J. Foss: Resources and Transaction Costs: How the Economics of Property Rights Furthers the Resource-based View

2004-10: Jens Gammelgaard \& Thomas Ritter: The Knowledge Retrieval Matrix: Codification and Personification as Separate Strategies

2004-11: Nicolai J. Foss \& Peter G. Klein: Entrepreneurship and the Economic Theory of the Firm: Any Gains from Trade?

2004-12: Akshey Gupta \& Snejina Michailova: Knowledge Sharing in Knowledge-Intensive Firms: Opportunities and Limitations of Knowledge Codification

2004-13: Snejina Michailova \& Kate Hutchings: Knowledge Sharing and National Culture: A Comparison Between China and Russia

\section{5}

2005-1: Keld Laursen \& Ammon Salter: My Precious - The Role of Appropriability Strategies in Shaping Innovative Performance

2005-2: Nicolai J. Foss \& Peter G. Klein: The Theory of the Firm and Its Critics: A Stocktaking and Assessment

2005-3: Lars Bo Jeppesen \& Lars Frederiksen: Why Firm-Established User Communities Work for Innovation: The Personal Attributes of Innovative Users in the Case of Computer-Controlled Music

2005-4: Dana B. Minbaeva: Negative Impact of HRM Complementarity on Knowledge Transfer in MNCs

2005-5: Kirsten Foss, Nicolai J. Foss, Peter G. Klein \& Sandra K. Klein: Austrian Capital 
Theory and the Link Between Entrepreneurship and the Theory of the Firm

2005-1: Nicolai J. Foss: The Knowledge Governance Approach

2005-2: Torben J. Andersen: Capital Structure, Environmental Dynamism, Innovation Strategy, and Strategic Risk Management

2005-3: Torben J. Andersen: A Strategic Risk Management Framework for Multinational Enterprise

2005-4: Peter Holdt Christensen: Facilitating Knowledge Sharing: A Conceptual Framework

2005-5 Kirsten Foss \& Nicolai J. Foss: Hands Off! How Organizational Design Can Make Delegation Credible

2005-6 Marjorie A. Lyles, Torben Pedersen \& Bent Petersen: Closing the Knowledge Gap in Foreign Markets - A Learning Perspective

2005-7 Christian Geisler Asmussen, Torben Pedersen \& Bent Petersen: How do we Capture "Global Specialization" when Measuring Firms' Degree of internationalization?

2005-8 Kirsten Foss \& Nicolai J. Foss: Simon on Problem-Solving: Implications for New Organizational Forms

2005-9 Birgitte Grøgaard, Carmine Gioia \& Gabriel R.G. Benito: An Empirical Investigation of the Role of Industry Factors in the Internationalization Patterns of Firms

2005-10 Torben J. Andersen: The Performance and Risk Management Implications of Multinationality: An Industry Perspective

2005-11 Nicolai J. Foss: The Scientific Progress in Strategic Management: The case of the Resource-based view

2005-12 Koen H. Heimeriks: Alliance Capability as a Mediator Between Experience and Alliance Performance: An Empirical Investigation Into the Alliance Capability Development Process

2005-13 Koen H. Heimeriks, Geert Duysters \& Wim Vanhaverbeke: Developing Alliance Capabilities: An Empirical Study

2005-14 JC Spender: Management, Rational or Creative? A Knowledge-Based Discussion

\section{6}

2006-1: Nicolai J. Foss \& Peter G. Klein: The Emergence of the Modern Theory of the Firm

2006-2: Teppo Felin \& Nicolai J. Foss: Individuals and Organizations: Thoughts on a Micro-Foundations Project for Strategic Management and Organizational Analysis

2006-3: Volker Mahnke, Torben Pedersen \& Markus Venzin: Does Knowledge Sharing 
Pay? An MNC Subsidiary Perspective on Knowledge Outflows

2006-4: Torben Pedersen: Determining Factors of Subsidiary Development

2006-5 Ibuki Ishikawa: The Source of Competitive Advantage and Entrepreneurial Judgment in the RBV: Insights from the Austrian School Perspective

2006-6 Nicolai J. Foss \& Ibuki Ishikawa: Towards a Dynamic Resource-Based View: Insights from Austrian Capital and Entrepreneurship Theory

2006-7 Kirsten Foss \& Nicolai J. Foss: Entrepreneurship, Transaction Costs, and Resource Attributes

2006-8 Kirsten Foss, Nicolai J. Foss \& Peter G. Klein: Original and Derived Judgement: An Entrepreneurial Theory of Economic Organization

2006-9 Mia Reinholt: No More Polarization, Please! Towards a More Nuanced Perspective on Motivation in Organizations

2006-10 Angelika Lindstrand, Sara Melen \& Emilia Rovira: Turning social capital into business? A study of Swedish biotech firms' international expansion

2006-11 Christian Geisler Asmussen, Torben Pedersen \& Charles Dhanaraj: Evolution of Subsidiary Competences: Extending the Diamond Network Model

2006-12 John Holt, William R. Purcell, Sidney J. Gray \& Torben Pedersen: Decision Factors Influencing MNEs Regional Headquarters Location Selection Strategies

2006-13 Peter Maskell, Torben Pedersen, Bent Petersen \& Jens Dick-Nielsen: Learning Paths to Offshore Outsourcing - From Cost Reduction to Knowledge Seeking

2006-14 Christian Geisler Asmussen: Local, Regional or Global? Quantifying MNC Geographic Scope

2006-15 Christian Bjørnskov \& Nicolai J. Foss: Economic Freedom and Entrepreneurial Activity: Some Cross-Country Evidence

2006-16 Nicolai J. Foss \& Giampaolo Garzarelli: Institutions as Knowledge Capital: Ludwig M. Lachmann's Interpretative Institutionalism

2006-17 Koen H. Heimriks \& Jeffrey J. Reuer: How to Build Alliance Capabilities

2006-18 Nicolai J. Foss, Peter G. Klein, Yasemin Y. Kor \& Joseph T. Mahoney: Entrepreneurship, Subjectivism, and the Resource - Based View: Towards a New Synthesis

2006-19 Steven Globerman \& Bo B. Nielsen: Equity Versus Non-Equity International Strategic Alliances: The Role of Host Country Governance

\section{7}

2007-1 Peter Abell, Teppo Felin \& Nicolai J. Foss: Building Micro-Foundations for the Routines, Capabilities, and Performance Links 
2007-2 Michael W. Hansen, Torben Pedersen \& Bent Petersen: MNC Strategies and Linkage Effects in Developing Countries

2007-3 Niron Hashai, Christian G. Asmussen, Gabriel R.G. Benito \& Bent Petersen: Predicting the Diversity of Foreign Entry Modes

2007-4 Peter D. Ørberg Jensen \& Torben Pedersen: Whether and What to Offshore?

2007-5 Ram Mudambi \& Torben Pedersen: Agency Theory and Resource Dependency Theory: Complementary Explanations for Subsidiary Power in Multinational Corporations

2007-6 Nicolai J. Foss: Strategic Belief Management

2007-7 Nicolai J. Foss: Theory of Science Perspectives on Strategic Management Research: Debates and a Novel View

2007-8 Dana B. Minbaeva: HRM Practices and Knowledge Transfer in MNCs

2007-9 Nicolai J. Foss: Knowledge Governance in a Dynamic Global Context: The Center for Strategic Management and Globalization at the Copenhagen Business School

2007-10 Paola Gritti \& Nicolai J. Foss: Customer Satisfaction and Competencies: An Econometric Study of an Italian Bank

2007-11 Nicolai J. Foss \& Peter G. Klein: Organizational Governance

2007-12 Torben Juul Andersen \& Bo Bernhard Nielsen: The Effective Ambidextrous Organization: A Model of Integrative Strategy Making Processes.

\section{8}

2008-1 Kirsten Foss \& Nicolai J. Foss: Managerial Authority When Knowledge is Distributed: A Knowledge Governance Perspective

2008-2 Nicolai J. Foss: Human Capital and Transaction Cost Economics.

2008-3 Nicolai J. Foss \& Peter G. Klein: Entrepreneurship and Heterogeneous Capital.

2008-4 Nicolai J. Foss \& Peter G. Klein: The Need for an Entrepreneurial Theory of the Firm.

2008-5 Nicolai J. Foss \& Peter G. Klein: Entrepreneurship: From Opportunity Discovery to Judgment.

2008-6 Mie Harder: How do Rewards and Management Styles Influence the Motivation to Share Knowledge?

2008-7 Bent Petersen, Lawrence S. Welch \& Gabriel R.G. Benito: Managing the Internalisation Process - A Theoretical Perspective.

2008-8 Torben Juul Andersen: Multinational Performance and Risk Management Effects: Capital Structure Contingencies. 
2008-9 Bo Bernard Nielsen: Strategic Fit and the Role of Contractual and Procedural Governance in Alliances: A Dynamic Perspective.

2008-10 Line Gry Knudsen \& Bo Bernhard Nielsen: Collaborative Capability in R\&D Alliances: Exploring the Link between Organizational and Individual level Factors.

2008-11 Torben Juul Andersen \& Mahesh P. Joshi: Strategic Orientations of Internationalizing Firms: A Comparative Analysis of Firms Operating in Technology Intensive and Common Goods Industries.

2008-12 Dana Minbaeva: HRM Practices Affecting Extrinsic and Intrinsic Motivation of Knowledge Receivers and their Effect on Intra-MNC Knowledge Transfer.

2008-13 Steen E. Navrbjerg \& Dana Minbaeva: HRM and IR in Multinational Corporations: Uneasy Bedfellows?

2008-14 Kirsten Foss \& Nicolai J. Foss: Hayekian Knowledge Problems in Organizational Theory.

2008-15 Torben Juul Andersen: Multinational Performance Relationships and Industry Context.

2008-16 Larissa Rabbiosi: The Impact of Subsidiary Autonomy on MNE Knowledge Transfer: Resolving the Debate.

2008-17 Line Gry Knudsen \& Bo Bernhard Nielsen: Organizational and Individual Level Antecedents of Procedural Governance in Knowledge Sharing Alliances.

2008-18 Kirsten Foss \& Nicolai J. Foss: Understanding Opportunity Discovery and Sustainable Advantage: The Role of Transaction Costs and Property Rights.

2008-19 Teppo Felin \& Nicolai J. Foss: Social Reality, The Boundaries of Self-fulfilling Prophecy, and Economics.

2008-20 Yves Dos, Nicolai J. Foss \& José Santos: A Knowledge System Approach to the Multinational Company: Conceptual Grounding and Implications for Research

2008-21 Sabina Nielsen \& Bo Bernhard Nielsen: Why do Firms Employ foreigners on Their Top Management Teams? A Multi-Level Exploration of Individual and Firm Level Antecedents

2008-22 Nicolai J. Foss: Review of Anders Christian Hansen's “Uden for hovedstrømmen - Alternative strømninger i økonomisk teori"

2008-23 Nicolai J. Foss: Knowledge, Economic Organization, and Property Rights

2008-24 Sjoerd Beugelsdijk, Torben Pedersen \& Bent Petersen: Is There a Trend Towards Global Value Chain Specialization? - An Examination of Cross Border Sales of US Foreign Affiliates 
2008-25 Vikas Kumar, Torben Pedersen \& Alessandro Zattoni: The performance of business group firms during institutional transition: A longtitudinal study of Indian firms

2008-26 Sabina Nielsen \& Bo B. Nielsen: The effects of TMT and Board Nationality Diversity and Compensation on Firm Performance

2008-27 Bo B. Nielsen \& Sabina Nielsen: International Diversification Strategy and Firm Performance: A Multi-Level Analysis of Firm and Home Country Effects

\section{9}

2009-1 Nicolai J. Foss: Alternative Research Strategies in the Knowledge Movement: From Macro Bias to Micro-Foundations and Multi-Level Explanation

2009-2 Nicolai J. Foss \& Peter G. Klein: Entrepreneurial Alertness and Opportunity Discovery: Origins, Attributes, Critique

2009-3 Nicolai J. Foss \& Dana B. Minbaeva: Governing Knowledge: The Strategic Human Resource Management Dimension

2009-4 Nils Stieglitz \& Nicolai J. Foss: Opportunities and New Business Models: Transaction Cost and Property Rights Perspectives on Entrepreneurships

2009-5 Torben Pedersen: Vestas Wind Systems A/S: Exploiting Global R\&D Synergies

2009-6 Rajshree Agarwal, Jay B. Barney, Nicolai J. Foss \& Peter G. Klein: Heterogeneous Resources and the Financial Crisis: Implications of Strategic Management Theory

2009-7 Jasper J. Hotho: A Measure of Comparative Institutional Distance

2009-8 Bo B. Nielsen \& Sabina Nielsen: The Impact of Top Management Team Nationality Diversity and International Experience on Foreign Entry Mode

2009-9 Teppo Felin \& Nicolai Juul Foss: Experience and Repetition as Antecedents of Organizational Routines and Capabilities: A Critique of Behaviorist and Empiricist Approaches

2009-10 Henk W. Volberda, Nicolai J. Foss \& Marjorie E. Lyles: Absorbing the Concept of Absorptive Capacity: How To Realize Its Potential in the Organization Field

2009-11 Jan Stentoft Arlbjørn, Brian Vejrum Wæhrens, John Johansen \& Torben Pedersen: Produktion i Danmark eller offshoring/outsourcing: Ledelsesmæssige udfordringer 


\section{0}

2010-1 Dana B. Minbaeva, Kristiina Mäkelä \& Larissa Rabbiosi: Explaining Intraorganizational Knowledge Transfer at the Individual Level

2010-2 Dana B.Minbaeva \& Torben Pedersen: Governing Individual Knowledge Sharing Behavior

2010-3 Nicolai J. Foss \& Peter G. Klein: Alertness, Judgment, and the Antecedents of Entrepreneurship

2010-4 Nicolai J.Foss \& Joseph T.Mahoney: Exploring Knowledge Governance

2010-5 Jasper J. Hotho, Florian Becker-Ritterspach \& Ayse Saka-Helmhout: Enriching Absorptive Capacity Through Social Interaction

2010-6 Nicolai J. Foss \& Bo B. Nielsen: Researching Collaborative Advantage: Some Conceptual and Multi-level Issues

2010-7 Nicolai J. Foss \& Nils Stieglitz: Modern Resource-Based Theory(ies)

2010-8 Christian Bjørnskov \& Nicolai J. Foss: Do Economic Freedom and Entrepreneurship Impact Total Factor Productivity?

2010-9 Gabriel R.G. Benito, Bent Petersen \& Lawrence S. Welch: Mode Combinations and International Operations: Theoretical Issues and an Empirical Investigation

\section{1}

2011-1 Peter D. Ørberg Jensen \& Bent Petersen: Human Asset Internalization and Global Sourcing of Services - A Strategic Management Analysis on Activity-level

2011-2 Mie Harder: Management Innovation Capabilities: A Typology and Propositions for Management Innovation Research

2011-3 Mie Harder: Internal Antecedents of Management Innovation: The effect of diagnostic capability and implementation capability 
2011-4 Mie Harder: Explaining Management Innovation Pervasiveness: The Role of Internal Antecedents

2011-5 Mie Harder: Internal Determinants of Product Innovation and Management Innovation: The Effect of Diagnostic Capability and Implementation Capability

2011-6 Nicolai J. Foss, Peter G. Klein \& Per L. Bylund: Entrepreneurship and the Economics of the Firm

2011-7 Nicolai J. Foss \& Jacob Lyngsie: The Emerging Strategic Entrepreneurship Field: Origins, Key Tenets and Research Gaps

2011-8 Nicolai J. Foss: Entrepreneurship in the Context of the Resource-based View of the Firm

2011-9 Bent Petersen, Gabriel R.G. Benito, Olesya Dovgan \& Lawrence Welch: Offshore outsourcing: A dynamic, operation mode perspective

2011-10 Bent Petersen, Gabriel R. G. Benito \& Lawrence Welch: Dynamics of Foreign Operation Modes and their Combinations: Insights for International Strategic Management

2011-11 Nicolai J. Foss: Teams, Team Motivation, and the Theory of the Firm

2011-12 Nicolai J. Foss: Knowledge Governance: Meaning, Nature, Origins, and Implications

2011-13 Nicolai J. Foss, Kirsten Foss \& Phillip C. Nell: MNC Organizational Form and Subsidiary Motivation Problems: Controlling Intervention Hazards in the Network MNC

2011-14 Kåre Moberg: Evaluating Content Dimensions in Entrepreneurship Education

\section{2}

2012-1 Nicolai J. Foss, Nicholas Argyres, Teppo Felin \& Todd Zenger: The Organizational Economics of Organizational Capability and Heterogeneity: A Research Agenda 
2012-2 Torben J. Andersen, Carina Antonia Hallin \& Sigbjørn Tveterås: A Prediction Contest: The Sensing of Frontline Employees Against Executive Expectations

2012-3 Peter G. Klein, Jay B. Barney \& Nicolai J. Foss: Strategic Entrepreneurship

2012-4 Kåre Moberg: The Impact of Entrepreneurship Education and Project-based Education on Students' Personal Development and Entrepreneurial Intentions at the Lower Levels of the Educational System: Too Much of Two Good Things?

2012-5 Keld Laursen \& Nicolai J. Foss: Human Resource Management Practices and Innovation

2012-6 Kåre Moberg: An Entrepreneurial Self-Efficacy Scale with a Neutral Wording 